Florida State University College of Law

Scholarship Repository

Scholarly Publications

Winter 2009

\title{
The Significance of Private Burdens and Lost Benefits for a Fair- Play Analysis of Punishment
}

Shawn J. Bayern

Florida State University College of Law

Follow this and additional works at: https://ir.law.fsu.edu/articles

Part of the Criminal Law Commons

\section{Recommended Citation}

Shawn J. Bayern, The Significance of Private Burdens and Lost Benefits for a Fair-Play Analysis of Punishment, 12 NEW CRIM. L. REV. 1 (2009),

Available at: https://ir.law.fsu.edu/articles/48

This Article is brought to you for free and open access by Scholarship Repository. It has been accepted for inclusion in Scholarly Publications by an authorized administrator of Scholarship Repository. For more information, please contact efarrell@law.fsu.edu. 


\section{THE SIGNIFICANCE OF PRIVATE BURDENS AND LOST BENEFITS FOR A FAIR-PLAY ANALYSIS OF PUNISHMENT}

Shawn J. Bayern*

This article considers the relevance of several kinds of post-offense events for the justice of punishment under a fair-play account of retributivism. If the justice of punishment depends on something like an offender-centered tally of benefits and burdens, it may be difficult to explain why offenders should be punished by a criminal justice system in situations where they have been punished privately or have lost the relevant benefits they may have received from their offenses.

My fault is past. But, $O$, what form of prayer

Can serve my turn? 'Forgive me my foul murder?'

That cannot be; since I am still possess'd

Of those effects for which I did the murder,

My crown, mine own ambition and my queen.

May one be pardon'd and retain the offence?

-King Claudius, Hamlet, Act III, Sc. III

\section{INTRODUCTION}

Herbert Morris's "fair-play" account of retributivism explains punishment as an attempt to restore a fair balance between burdens and benefits. Benefits accrue unfairly to offenders from their crimes, and punishment

*Visiting Assistant Professor of Law, Duke Law School. I am particularly indebted to Peter Westen for introducing me to retributivist theory and for advice and comments on an early draft of this article. I also wish to thank Martin Golding, Sapna Kumar, and Zephyr Teachout for helpful discussion. I do not thank Dostoevsky, for this is an article on punishment and time that is, for once, not called "Time and Punishment."

New Criminal Law Review, Vol. I2, Number I, pps I-42. ISSN 1933-4192, electronic ISSN 1933-4206. (C) 2009 by the Regents of the University of California. All rights reserved. Please direct all requests for permission to photocopy or reproduce article content through the University of California Press's Rights and Permissions website, http://www. ucpressjournals.com/reprintInfo.asp. DOI: 10.1525/nclr.2009.I2.I.I. 
imposes corresponding burdens. Because of the necessary interval between crime and punishment, however, events following an offender's crime may restore a fair balance between burdens and benefits before the state can effect punishment. This article explores the implications of such events on the justice of punishment under a fairness-based theory.

More specifically, this article considers several classes of situations in which an offender's position has changed since the occurrence of a crime such that punishment may be unjust. These situations fall into two broad categories: (I) those in which the offender has suffered a burden as a result of the crime from a source other than punishment by the state, and (2) those in which an offender does not retain any "benefit" from her crime at the time punishment would be imposed. Punishment in either of these situations may be unjust under an account that depends on a comparison between benefits from crime and burdens from punishment.

In my discussions of punishment, I am concerned chiefly with the hard treatment imposed by the state, for it is this treatment that the benefitand-burden analysis seeks to explain. In the situations I consider, I do not believe that events that occur after an offense is committed undermine other features of punishment, such as a state's decision to denounce the offense or to blame its offender.

This article is not a general study of repentance, forgiveness, or pardon. Those notions share a concern with the passage of time, but my goal here is not to identify the general set of conditions under which an offender may justifiably repent, seek forgiveness, or be granted a pardon.' Indeed, repentance and similar processes may remove opportunities for blame, ${ }^{2}$ whereas blame, as I have just noted, may well still be appropriate in the situations I describe. My goal instead is to identify problems for fair-play accounts of retributivism that, though absent under a temporally static view of offenders and their crimes (in which crime and punishment are

I. For an example of such a study, as well as a discussion of the distinction between repentance, forgiveness, and pardon, see Meir Dan-Cohen, Revising the Past: On the Metaphysics of Repentance, Forgiveness, and Pardon, in Forgiveness, Mercy, and Clemency II7 (Austin Sarat \& Nasser Hussain eds., 2007).

2. See id. at 117-18 (outlining conditions that remove opportunities for appropriate "guilt," "resentment," and "stigma," which I take to be three sorts of blame that might arise from a crime). 
imagined, at least implicitly, ${ }^{3}$ to occur simultaneously), arise when we consider the necessary lapse of time between offenses and their punishments.

Moreover, in considering what I call the "justice" of punishment, my concern is only whether any difference in desert remains between an innocent person and an offender who, after a lapse of time, retains no advantage compared to innocent people. The effects of any such moral difference matter differently to so-called strong retributivists (who hold desert to be sufficient for punishment) and weak retributivists (who maintain that desert is necessary for punishment but that it may not be sufficient) ${ }^{4}$ but I am not concerned in this article with the merits of either view.

Given my aim-to complicate fair-play theory by demonstrating that offenders are often punished in situations that the theory cannot explain, as a result of its insensitivity to time-two alternative results are possible if I succeed. ${ }^{5}$ For those who accept that punishment depends on fairness or a view of fair play, my analysis suggests that punishment is in fact unjust in situations not previously recognized. For critics of the fair-play account, on the other hand, the problems I raise may serve only to bolster

3. Commentators' explicit language does sometimes nod toward the time difference. See, e.g., R.A. Duff, Trials and Punishments 210 (1986) ("[Fair-play theory attempts to explain] the relationship between present penal suffering and past criminal wrong-doing."). Nonetheless, the view of punishment commentators adopt tends to be what I have called temporally static: the analyses do not consider the porential importance of events that occur between crime and punishment.

4. See, e.g., Stephen P. Garvey, "As the Gentle Rain from Heaven": Mercy in Capital Sentencing, 81 Cornell L. Rev. 989, I012-13 (1996) ("[S]trong retributivism . . places an obligation on the sentencer to impose the punishment the offender deserves. . . [W] [Wak retributivism . . . merely authorizes the sentencer to impose the deserved punishment."); cf. also Mark C. Murphy, Natural Law in Jurisprudence and Politics 145 (2006) (using the term "extra-strong retributivism" to refer to the view that punishment is mandatory to redress crime and "strong retributivism" to refer merely to the notion that "the point of punishment is to respond to the crime by punishing").

5. A step in my analysis involves elucidating the boundaries of relevant benefits and burdens considered by fair-play theory, and this step might separately shed light on the theory's plausibility. For instance, to characterize fair-play theory (as I do in Part II) as concerned with distributive fairness but sensitive only to some kinds of distributional effects is to suggest that fair-play theory makes particular choices about which kinds of distributive changes are important and which are not. (I describe these choices more precisely in Part II.) Greater attention to these boundaries is important, and it can of course help us see whether fair-play theory in its current form (and the punishment that it justifies) is morally acceptable in the first place. 
their criticism. ${ }^{6}$ My goal here is neither to attack nor defend fair-play theory wholesale, so I don't argue vigorously for one of these alternative interpretations of my analysis over the other.

In any event, the substantive questions I raise in this article (such as whether offenders who have suffered in particular ways as the result of their crimes deserve less punishment) appear to raise problems for other accounts of punishment, such as other retributive theories and even utilitarianism. These problems are beyond this article's scope, but throughout the article I occasionally indicate, in passing, how an issue I have identified may raise complications for other theories of punishment.

\section{PRIVATE BURDENS}

The fair-play theory of punishment suggests that the state punishes in order to redress a distributive imbalance: ${ }^{7}$

[I]t is just to punish those who have violated the rules and caused the unfair distribution of benefits and burdens. A person who violates the rules has

6. As an analogy, consider the objection to fair-play theory that it does not adequately explain punishment for cruelty to animals, an offense that seems to lead to no unfairness to humans. See Richard Burgh, Do the Guilty Deserve Punishment, 79 J. Phil. 193, 205 (1982); C.L. Ten, Crime, Guilt, and Punishment 63 (1987). Accepting for argument's sake the objection's validity (even though I have doubts about it), one possible interpretation (which Burgh and Ten adopt) is that Morris's theory is an incomplete account of punishment, and that we may have to look elsewhere to understand or justify punishment. See Burgh, supra, at 205; Ten, supra, at 63 . But another interpretation, of course, is that it is unjust to punish people for cruelty to animals (even if other means to prevent such cruelty are desirable)at least without an expanded notion of fairness that incorporates animals' well-being. I don't mean to take a position on punishment for animal cruelty here; I just mean to show that more than one interpretation of a limitation in fair-play's analytical range is possible.

7. The association between punishment and fair play is thought to originate with Herbert Morris. See Herbert Morris, Persons and Punishment, 52 The Monist 475, 477-80 (1968), reprinted in Herbert Morris, On Guilt and Innocence: Essays in Legal Philosophy and Moral Psychology 31, 33-36 (1976). Others have advanced similar accounts, and many believe that fair-play theory in some form is the most appealing nonconsequentialist defense of punishment. See Leo Zaibert, Punishment and Retribution 117 \& n.67 (2006) (listing sources and, though critical himself of fair-play theory for other reasons, finding that it is still popular and recognizing that when legal rights are violated-as opposed to entirely private cases of punishment, like those between friends or by parents to their children- "a case can be made that punishment sometimes is justified because it helps restore 
something others have - the benefits of the system-but by renouncing what others have assumed, the burdens of self-restraint, he has acquired an unfair advantage. Matters are not even until this advantage is in some way erased. Another way of putting it is that he owes something to others, for he

the cooperative playing field to an initial level of fairness"); Michael Moore, Placing Blame: A General Theory of the Criminal Law 106, 170 n.29 (1997) (referring to fair-play theory as "plausible" and stating that it "may survive the by-now voluminous criticisms made of it"); Wojciech Sadurski, Theory of Punishment, Social Justice, and Liberal Neutrality, 7 L. \& Phil. 351, 356 (1989) ("[Punishment] is a redistribution after [a] wrongful distribution . . has taken place."); George Sher, Desert 69-90 (1987); John Finnis, Natural Law and Natural Rights 263 (1980) ("IP] unishment rectifies the disturbed pattern of distribution of advantages and disadvantages throughout a community . . . ."); Jeffrie Murphy, Retribution, Justice, and Therapy 77-78 (1979) (defending a form of retributivism based on the notion that "it is important to guarantee that those who disobey will not thereby gain an unfair advantage over those who obey voluntarily"); John Cottingham, Varieties of Retribution, 29 Phil. Q. 238, 246 (1979) ("[T]he fair play theory ... seems to me to have the best chance of providing a non-utilitarian rationale for the practice of punishment."). The fair-play account of punishment has no shortage of critics. Some of the criticism centers on whether the account is retributive or even nonconsequentialist in the first place. See Zaibert, supra, at I18; Cottingham, supra, at 243, 246. Even Morris's original account speaks at least in passing of deterrence. See Morris, supra, at 478 (referring to the "incentive . . provided individuals to restrain their inclinations," which decreases "the incidence of persons taking what they do not deserve"). I am, however, not concerned here with the appropriate classification of the fair-play account; nothing I say here is meant to depend on precisely how "retributive" or backward-looking the theory is.

Others attack the theory on substantive grounds. See, e.g., Matt Matravers, Justice and Punishment: The Rationale of Coercion 52-72 (2000) (summarizing and building upon criticism of the theory). For many, questions about what sort of "benefit" accompanies offenses-either in general, see David Dolinko, Some Thoughts About Retributivism, Ior Ethics 537 (199I), or in particular cases, like unintentional crimes, see Zaibert, supra, at 122-23 - lead to doubt that benefits from crime have an important role to play in justifying punishment. Because my goal here is not specifically to defend fair-play theory, these general criticisms of it are beyond my scope, but the explanation of possible benefits that I provide in Part III may be useful to help frame the discussion among critics.

Matravers makes a separate criticism of fair-play theory: he believes it has failed as an independent account of the justice of punishment, not tied to a particular substantive account of criminal law. But even accepting Matravers's conclusion that fair-play theory is "incomplete" and that it depends on a particular "understanding of society [and] the character of the benefits and burdens enjoyed by, and imposed on, citizens," id. at 53-that is, that it is tied to a substantive account of criminal law and does not provide "a relatively independent justification of punishment," id.-this article's analysis still applies. That is, even a fair-play theory tied to a substantive account of criminal law would need either to accept or to wrestle with my conclusions that private punishment and lost benefits may remove the moral justifications for state-impose punishment. 
has something that does not rightfully belong to him. Justice-that is punishing such individuals-restores the equilibrium of benefits and burdens by taking from the individual what he owes, that is, exacting the debt. ${ }^{8}$

I take up in Part III what sort of "unfair advantage" an offender may acquire from a crime and what can happen to this advantage over time. For now, assume that an offender, in committing an offense, does in fact acquire such an advantage and that punishment is just in removing it.

\section{A. Punishment, Distribution, and Transactional Justice}

Though his account is essentially distributive, Morris is of course not suggesting that we adopt punishment as a universal tool to redress all distributive problems (such as those that arise from unfair historical distributions of wealth or from strict-liability torts). It would not be conceptually impossible to use "punishment" that way; for instance, if equality were an overriding ideal and a state were confident in its ability to detect distributive unfairness, the state might conceivably hurt people to create equality by destroying any differences in utility that it perceived as unfair or unearned. ${ }^{9}$ But this would be a bizarre use of punishment, and it surely is not what Morris is intending to justify.

Instead, Morris's justification is presumably limited to punishment in response to a crime. This limitation may seem obvious, but in analyzing a fair-play account of punishment, it is important to recognize that the benefits and burdens under discussion appear to be limited to those that arise causally from an offense. ${ }^{10}$ Other distributive problems presumably have other solutions; Morris presents punishment simply as a way to impose fair burdens on those who "have a fair opportunity to comply with the rules" but choose not to do so and receive a benefit as a result." In other

8. Morris, supra note 7 , at 478 .

9. I do not take seriously supposed conceptual limitations on "punishment" that work merely as redefinitions of the term-e.g., the suggestion that punishment is nor punishment if it is not imposed justly in response to a criminal offense. Cf. H.L.A. Hart, Prolegomenon to the Principles of Punishment, in Punishment and Responsibility I, 5 (1968) (discussing what Hart calls a "definitional stop").

10. This does not imply that all results of a crime, however distant or attributable to other events, are relevant to fair-play analysis. See the final paragraph of Part II.B, infra; cf. also infra note 32.

II. Morris, supra note 7 , at 478 . 
words, in tallying burdens and benefits to determine whether punishment is just, we are apparently considering, at most, only those benefits and burdens that are caused by an offense. An offender gets something she doesn't deserve from committing an offense (and fair-play analysis isn't concerned with other benefits she might have); she is punished in response to this offense (and fair-play analysis isn't concerned with other burdens she might have suffered). ${ }^{12}$

Of course, we are not required to restrict our view of benefits and burdens in this way, and indeed some of our moral intuitions are global - they aim to tally all information available about an offender and the her circumstances. For instance, Gertrude Ezorsky has described a "whole life view of criminal desert" under which justice "would require that one balance all of [an offender's] moral wrongs against the suffering of his entire life."'3 A broad view of "fair" burdens and benefits, even in the criminal

12. Of course, that people recognize the causal connection between crime and punishment is important if punishment is meant to deter crime, and perhaps for other consequentialist or expressive reasons. Consider, for instance, the following analysis:

Some stranger insults you in a public place. You try to console yourself by imagining that the obnoxious person has a miserable life. The response is not wholly satisfying, however, because you want the transgressor to be miserable because of her transgression against you so that she links the two and sees how she has brought the suffering on herself by being bad.

Sherry Colb, Oil and Water: Why Retribution and Repentance Do Not Mix, 22 Quinnipiac L. Rev. 59 (2004). At the risk of sounding too forgiving among those who discuss retributive punishment, I have to admit that the situation Colb describes is somewhat alien to me; I am typically perhaps so focused on trying to end encounters with erratic and insulting strangers that I have no wish, in the moment or thereafter, that their lives are miserable. But even accepting on consequentialist grounds Colb's notion that a causal link between offense and punishment is important because of what that link makes people realize about offenses, my goal in emphasizing causation is different: I am saying that when we pay attention to views of justice that I shall call transactional, the problem with a transgressor suffering for reasons unrelated to the transgression is simply that the transgression itself still goes unpunished. That is, I shall suggest that fair-play theory identifies a transactional framework in which only certain features of the world matter in making decisions about fair punishment.

13. Philosophical Perspectives on Punishment at xxxvi (Gertrude Ezorsky ed., 1972). Translating such a view into Morris's terms, the general burdens offenders may have faced throughout their lives could offset the specific benefits they draw from crimes.

I do not mean specifically to argue against this view, and I certainly do not mean to suggest that the background hardships of an offender's life are irrelevant to questions of punishment, as, for instance, the U.S. Sentencing Guidelines Manual does. See U.S. 
context, could aim to consider the background conditions that have led people to act in the way that they did.

Nonetheless, we harbor separate intuitions about fairness that are transactional - that is, that consider only a limited group of interactions between people when determining the fairness of a particular activity. ${ }^{14} \mathrm{We}$ may, for instance, think that one acts "unfairly" by cutting in line, even if one has been unfairly delayed by others in the past-even in the very recent past - in precisely the same way. The parameters of this sense of fairness, and our determination of how exactly we draw brackets, are complicated. ${ }^{15}$ We sympathize with people because of the prior burdens they have experienced, but we may also believe that we all experience burdens and yet do not—and should not-make decisions ourselves about how to pass them on to innocent others. This may be just because our information about the world and our cognitive capacities are limited. In view of our limitations, we do not trust ourselves, or others, to assume that the individual burdens we know we face outweigh those of our potential victims, such that we can fairly force a redistribution of these burdens on our own (or even fairly ask that such a redistribution be effected). Though a transactional view of fairness-one that refuses to consider features of the world that may well be relevant to a global view of what is fair-can be limited and harsh, we sometimes have no choice but to limit the field of information we evaluate in making decisions. Thus, for example, our intuitions about how fairly to split limited resources often tend to bracket out most information: whether I or my colleague should fairly get the last

Sentencing Guidelines Manual $\$ \varsigma \mathrm{HI}_{\mathbf{I}}(2005)$ (ruling out "education," "skills," "mental and emotional conditions," "physical condition, including drug or alcohol dependence," "employment record," "race," "sex," "socio-economic status," and "lack of guidance as a youth" as generally relevant in determining an offender's criminal sentence). As we shall see, my argument is instead that even within an account like Morris's, which does not pay attention to all information globally available about an offender, punishment may be unjust in the situations I consider in this article.

14. Daryl Levinson has used the term "transaction" similarly in a different context. See Daryl J. Levinson, Framing Transactions in Constitutional Law, III Yale L.J. 1311, 1313 (2002) ("The prevailing, classically liberal, model of tort, contract, and property cases features atomistic individuals who interact only at the point of a discontinuous event, sharply limited in space and time.").

15. For a more general and differently focused discussion on alternative ways to "construct" criminal activity, see generally Mark Kelman, Interpretive Construction in the Substantive Criminal Law, 33 Stan. L. Rev. 59I (1981). 
remaining bottle of water at a colloquium might depend on whether each of us has already gotten a beverage at the event, or perhaps even at the last colloquium, but probably not on broader features of the world (such as wealth differences between us or even the marginal utility the bottle of water is expected to yield to us) unless these differences are exceptional (such as a known medical condition that makes the bottle of water necessary to maintain health).

As another example, if someone dents my car in a parking lot and leaves no note claiming responsibility, I might be tempted to do the same if, two hours later, I accidentally dent someone else's car in the same way. After all, it seems "only fair" in some sense. But overall, we do not ordinarily think it is fair to allow people to make decisions like that, and probably not just because we don't trust them to make the decisions in an unbiased fashion. Instead of such mistrust, or at least in addition to it, our intuitions tell us that the prior wrong we have suffered (in this case, the earlier damage to my car) simply has no bearing on the fair assignment of burdens that results from a later "transaction" (in this case, the second dent). We can try to explain this intuition in several ways. For one thing, we don't know that the owner of the second car to be dented hasn't been previously wronged in the same way I have, or in another way that would make my passing the burden to him unfair. For another, we tend to think that I have some responsibility for the second dent because I caused it. Finally, more basically, we know we can't consider all information that might be relevant, and we have to draw the line somewhere. Drawing it in a way that corresponds to our ordinary sense of the salient boundaries between discrete events seems like a reasonable way to avoid drawing alternative lines that might be systematically less fair or harder to work with. We may simply rule some arguments out, even knowing that they could help us reach a better result, because we doubt that we have good ways to evaluate them.

I take Morris's account of punishment to reflect a transactional sense of justice based on intuitions similar to those I have been describing, rather than a broader view like Ezorsky's that attempts to address distributive issues that do not arise from crime. ${ }^{16}$ I do not wish to suggest that Morris's

16. My explanation of fair-play theory as concerned with discrete "transactions" differs somewhat from the more conventional view that fair-play punishment simply assumes that the distribution existing before an offense occurs is just. See, e.g., Matravers, supra note 7, at 5s (" $[A]$ lthough if there is to be a moral justification for punishment in the idea of restoring 
view is necessarily the better one. Instead, my argument is that even under a limited, transactional view of justice like Morris's, burdens other than official punishment by the state are relevant to our analysis. More specifically, an offender might suffer burdens as a result of her crime from a source other than official state punishment. Nothing in Morris's transactional account of justice gives us a reason, in principle, to exclude all of these burdens from consideration in determining the justice of punishment.

The next section considers some burdens of this type-those that result from crime but not from official punishment-and suggests that they can be sufficient to restore a just balance between burdens and benefits, making further official punishment thereby unjust.

\section{B. State Punishment as Potentially Redundant}

To begin with, consider the trivial observation that a state that punishes someone twice for the same crime, while purporting to punish all offenders only once for any crime, is clearly unjust on its own terms. Just punishment by the state for an offense entitles offenders to no further punishment for the same offense, and this obvious statement is consistent with Morris's account of punishment: once an unfair distribution of benefits and burdens is remedied, further punishment is unwarranted because it does not address a persisting inequity. But considering variations of this

some distribution of benefits and burdens it must be the case that the pattern of distribution to be restored is just, what defines such a distribution is not a question that fair play theory need address."). Both views avoid evaluating the fairness of the preexisting distribution, but a transactional view does not explicitly assume that that distribution is globally fair-an assumption that seems severely questionable in many societies. On a transactional view, punishment is appropriate not because it restores perfection but because it eliminates an identifiable transactional unfairness. Similarly, preventing someone from cutting in line or taking two meals at a conference does not imply that that person lives in a just society; it just establishes rules that are meant to govern discrete transactions fairly.

It is important to recognize a potential danger of transactional thinking: it shifts focus away from global fairness. That Nazi officials were "just following orders" is an extreme example of this, but the pattern may well occur in contexts that range from discussions of property-rights theory to affirmative action. The solution, however, is not necessarily to abandon all transactional thinking but instead to determine its appropriate bounds-the conditions under which it justly applies. Such a determination is of course beyond the scope of this article, but it is something I plan to elaborate in future work. 
situation will help us explore whether it is just for the state to punish offenders who have already suffered other kinds of burdens from their offenses. Consider first the following admittedly stylized situation:

$X$ commits a negligent homicide with $Y$, the victim's brother, as an eyewitness. Because $Y$ is not the most reliable character, he fears the police will not believe him when he reports the crime. (This is an example of what economic contract theorists describe as "observable" but not "verifable" information. $)^{17}$ Unable to tolerate the possibility that $X$ may escape with his crime, $Y$ immediately subdues him. Being an accomplished criminal lawyer, $Y$ knows precisely what the penalty would be if $X$ s crime were established in court. He goes to great lengths to construct a private prison in his basement that mirrors the conditions of the public prison in which $X$ would have been held had he been convicted for his crime, and he keeps $X$ there precisely as long as the state would have done. After the sentence expires, $Y$ flees the jurisdiction to avoid being punished for his vigilantism. The police capture $X$ and, because it turns out that he left evidence other than an eyewitness about which $Y$ was never aware, $X$ is subsequently convicted of negligent homicide.

In a situation like this, given $X^{\prime}$ s imprisonment under conditions matching those the state would have imposed, is it just to punish him again in precisely the same way for the same crime? Conventional wisdom-and current law ${ }^{18}$ - seems to assign great importance to the role of the punisher.

17. See, e.g., Robert E. Scott \& George G. Triantis, Incomplete Contracts and the Theory of Contract Design, 56 Case W. Res. L. Rev. 187, 191 (2005) (“Over the past twenty years or so, back-end obstacles have driven a large body of the theorists' models: namely, that some states of the world are not verifiable to a court, even though they may be observable to both the parties.").

I8. Cf. Rafferty v. State, 799 So. 2 2 243, 248 (Fla. Dist. Ct. App. 200I) ("It cannot be said that the legislature intended lesser punishments when the victims of offenses are family members or loved ones."); State v. Lacey, 553 So. $2 \mathrm{~d} 778,780$ (Fla. Dist. Ct. App. 1989) (rejecting the argument that effects on a defendant's "professional future" should affect sentencing); cf. also cases cited infra note 28.

Discretion in sentencing (which may incorporate considerations of mercy as well as justice) is another matter. In exercising discretion, sentencing judges do (as they should) at least occasionally look to harms that offenders suffer from non-state actors as a result of their offenses. See, e.g., Kate Murphy \& Alexei Barrionuevo, Fastow Sentenced to 6 Years, N.Y. Times, Sept. 26, 2006, at CI ("Judge Hoyt said he had to 'examine the relationship between justice and mercy.' Although Mr. Fastow had 'drunk the wine of greed,' the judge said, he had also been the 'subject of great persecution,' including anti-Semitic slurs and 
But on reflection, it is hard to see why it matters to an accounting of benefits and burdens whether $Y$ is a "state" or not."

The central reason for this is that if an account of punishment is based on distributional problems, and if it seeks to remedy unfair distributions by hurting people who have gained an unfair advantage, the proper focus is on the offender's suffering and not on who brings it about. In a system that addressed distributional problems through redistribution, the identity of the recipient of redistributed goods would obviously matter; a tort law that requires injurers to compensate the state instead of the victim, for example, does little to address the distributional problem between the injurer and the victim. But fair-play analysis in criminal law does nor redistribute any advantage; it restores fairness simply by removing an advantage. Nobody is meant to benefit from the burden imposed on offenders. In this sense the refrain that a punished offender "pays a debt to society" is only figurative-or, to say this differently, it is literally true (in a sense) but only an accidental feature of state-sanctioned punishment. Once the offender repays his "debt," an analysis based on distributive fairness that seeks to remove advantages from offenders leaves no room to ask, "To whom?" This is true even though an offender's unfair advantage comes in some sense at the expense of society as a whole.

Imprisonment is interestingly different from forced labor in this respect. An analogue to fair-play theory that literally required offenders to work for society's benefit as a way to pay back their debt to it could, on its own terms, be completely insensitive to private punishment. But on

personal threats."). Interestingly, at least one federal judge has entertained the possibility, albeit in the abstract and in passing, that an offender may deserve less state punishment "because he or she will receive extraordinary informal punishment in his or her ethnic community" - although "[p]resumably courts would grant requests for departure based on punishment outside of the legal system only extremely rarely." United States v. Yu, 954 F.2d 951, 958 \& n.5 (3d Cir. 1992) (Becker, J., dissenting). Judge Becker reasoned that convictions typically lead to social and professional losses, see id., and presumably it was therefore sensible to suppose that the federal sentencing guidelines were crafted with such informal losses in mind. As a result, "only the most unusual cases of extralegal punishment, whether culturally related or not, could warrant departure." Id. My analysis will suggest that on a fair-play analysis, at least Fastow's court was right to consider what it did: harms suffered at the hands of private parties as a result of an offense help eliminate whatever imbalance between benefits and burdens exist.

19. Recall that even under my view, nothing should prevent the state from blaming $X$; indeed, $X$ should be convicted, for he never was before. 
that theory, no punishment would be justified unless its goal were either to extract fines or to put prisoners to work for society's benefit. Modern theories of punishment, by contrast, seek to explain hard treatment on its own, not as a mechanism to effect a transfer to the state.

To identify the state as the necessary source of hard treatment under a fair-play view is, I think, to conflate fairness with other considerations (either retributive or utilitarian) about the proper administration of criminal justice. It is not controversial that criminal punishment ordinarily ought to come from the state. For one thing, the alternative is vigilantism. ${ }^{20}$ For another, a public system is likely necessary to detect crimes reliably, to ensure that crimes are addressed adequately and uniformly, and to ensure that punishment is properly monitored. The state may also play a communicative role in establishing norms and expressing society's disapproval of those who attempt to establish themselves in positions of superiority over others. ${ }^{21}$ All of this is true, and yet all of it is irrelevant in deciding

20. It is important to understand that my example of the fastidious vigilante who constructs a private prison is not meant to defend or justify vigilantism. The example is not meant to raise a question about whom we'd prefer to exact punishment; the question is simply whether it is just for the state to impose hard treatment after another entity has already imposed an appropriate measure of it (in this case, against the state's wishes).

Indeed, my view does not instrumentally encourage vigilantism, and at least as a theoretical matter it disincentivizes private punishment to the extent that it reduces the likelihood or severity of official punishment for those who suffer at the hands of vigilantes. I would not expect the effects of such a disincentive to be significant in most cases, but no instrumental concern about promoting vigilantism arises from my analysis.

2I. For example, Jaime Malamud-Goti has emphasized the importance of state punishment in locales that had previously allowed offenders to commit crimes with impunity:

Imagine a world in which certain people would never be punished no matter what they did to others. This environment depicts to a certain extent the Argentina or Chile of the seventies. In those days, the government systematically turned a blind eye to right-wing torturers and abductors. Subjected to a campaign of constant terror and having their complaints systematically shunned by the police and the courts, most non-sympathizers within the regime wound up sensing they were impotent before evil. Most of these people believed their ideas and activities justified their mishaps and those who did not had no alternative but to repress their own rage. Punishing the perpetrators would have raised [victims'] self-respect and esteem by either restoring their lost dignity or validating the outrage of the latter by conveying to them that they were right.

Jaime Malamud Goti \& Emma Zunz, Punishment and Sentiments, 22 Quinnipiac L. Rev. 45, $50(2004)$. Dan Markel has offered a more general account of the communicative role of punishment:

By making credible the threat to impose some level of punishment, the state is giving its best reasonable efforts to reduce the plausibility of individuals' false claims of superiority. The 
whether it is just under a fair-play account for the state to punish offenders who already have suffered appropriate burdens as a result of their crimes.

As a result, fair-play arguments for the necessity of state punishment end up seeming empty or circular. John Finnis, for instance, has asserted that only the state can restore the fair balance of benefits and burdens because such a restoration requires the offender to be subject to "the representative 'will of society' (the 'will' which he disregarded in disregarding the law)." ${ }^{22}$ However, beyond this assertion, Finnis offers no reason that only the state can be effective in addressing unfair advantages. That people have to be subject to the state's will is not a requirement grounded in distributive concerns. Moreover, it is not clear that convicted offenders who have suffered in ways the state acknowledges upon conviction are not already subject to society's representative will.

Further intuitions against considering private punishment in determining the justice of state punishment may arise from practical, administrative issues. Thus, we may believe that even in my example of the conscientious vigilante who constructs a faithful prison replica, evidence concerning the conditions of the offender's private imprisonment is unlikely to be sufficient to assure us that precisely the right level of punishment (or more) was meted out. I do not mean to suggest that these kinds of beliefs are invalid or unimportant, but if they are the only reason not to consider the relevance of private punishment in criminal cases, it is important to see them for what they are-pragmatic rather than moral

state's coercive measures communicate the norm of equal liberty under the law and they are directed to the person most in need of hearing it: the offender.

Dan Markel, State, Be Not Proud: A Retributivist Defense of the Commutation of Death Row and the Abolition of the Death Penalty, 40 Harv. C.R.-C.L. L. Rev. 407, 430-32 (2005). Markel claims that this role in part "explains why the state, rather than the victim or her allies, must be the agent imposing punishment." Id. at 427 . Whether this is correct for other theories of punishment is beyond my scope, but it is by no means clear to me that in cases where a defendant has already suffered private burdens as the result of a crime, the state need do anything more than convict and acknowledge these prior burdens in order to communicate the correct norms and prevent offenders from claiming a false superiority over others. In other words, state concern is state concern, regardless of whether the state is the source of hard treatment. And suffering can be sufficient to eliminate impunity and unfair dominance, even if the suffering doesn't come from the state.

22. John Finnis, The Restoration of Retribution, 32 Analysis 131, 133 (1972). 
considerations, founded in concerns about administrability rather than concerns about justice to individuals. And we ought to be careful about adopting general rules requiring that we ignore evidence of moral relevance. Whenever we adopt criminal-law rules wholesale, we understand that the undeserving may be made to suffer, even if we don't intend this. (We don't eliminate our whole criminal-justice system just because we know that it has the potential to convict innocent people.) Inappropriate suffering may be an unavoidable result in practice, but it is important to understand it and to attempt to minimize abuses.

If my example of the fastidious vigilante is not yet persuasive, consider what seems to be a more obvious but analogous case: imagine a succession of governments over time- $A, B$, and $C$-representing different states in the same geographical territory. Suppose $X$ commits a crime under regime $A$ and is punished by regime $B$. For the same reasons I have described in the case of wholly private punishment, it would be unjust for state $C$ to punish $X$ duplicatively, even if $A, B$, and $C$ never recognized the legitimacy of one another as states. I raise this example to suggest that the public nature of the punisher is not relevant when considering the justice of duplicative punishment: on what basis should the characteristics of regimes $A, B$, or $C$ (such as their constitutional nature, sovereign status, or international relations) influence what is, after all, an imbalance of benefits and burdens particular to an individual offender? Why should it matter to a tally of benefits and burdens whether $B$, say, is a sovereign state, an illegal regime, one of two powers competing for dominance in a territory, or even a private individual who has illegally declared herself queen?

Consider, similarly, a situation in which $X$, a citizen of state $A$, travels to state $B$ and commits a crime there for which both states punish offenders in the same way. Suppose $A$ does not recognize $B$ as a legitimate state, and vice versa, so that there are no formal mechanisms for recognizing convictions or punishments between the states. But suppose $X$ receives a fair trial in one state and is subsequently punished there. It again appears unjust under a fair-play account for the other state to punish $X$ in the same way.

Having suggested that the punishment need not come from the state in order to redress the unfair advantage that results from crime, I now want to suggest that the precise nature of the hard treatment need not match the state's in order to restore a fair equilibrium between benefits and burdens. Instead, all that matters is that the state judge the hard treatment 
that the offender suffered appropriate in extent to the crime. No easy generalizations can be made here; determinations about the appropriate measure of punishment for a particular crime are sensitive to context and relative to the punishment we impose for other crimes. Nonetheless, as a general matter, it is certainly possible that the state might judge punishments other than those it imposes itself to satisfy a retributive calculus and thereby to eliminate an unfair advantage.

For instance, consider the case of someone who recklessly kills a victim she loves; in cases like this, substantial punishment is inherent in the crime. Consider also cases where extreme suffering from emotional guilt is evident, ${ }^{23}$ or where an offender lives in abnormal fear that her crime will be exposed and she will thereby suffer severe reputational harm; ${ }^{24}$ in these cases, the offender punishes herself for the crime (or, alternatively, the punishment is partly inherent in the crime in such cases as well). Finally, consider cases where this reputational harm does result as a consequence of being apprehended for the crime; in such cases, other non-state actors punish the offender for the crime.

We are likely on reflection prepared to judge some burdens like this to be real and severe. Barring problems of proof (which are of course particularly difficult in the cases of offenders' own internal, emotional punishment of themselves), should we also be prepared to judge such burdens significant enough to offset the unfair benefit that the offender

23. In such cases, offenders may show themselves to have changed sufficiently to place them in the "benefits no longer relevant" category discussed in Part III, infra. And from a consequentialist perspective, this kind of remorse-if genuine --suggests the offender will be less dangerous in the future than a counterpart who does not exhibit it.

24. Of course, offenders may also fear state punishment. The particular burden associated with fearing punishment is a special case in some respects. For one thing, the state's criminal-law regime is responsible in part for this fear, so in some sense an offender who experiences this burden is being subjected to official punishment; at least, the state is a cause of the punishment. But this doesn't matter when we consider that if the state doesn't follow through on its threat to punish crimes, offenders will not fear such punishment; the burden of "fear of punishment" can't be imposed without actual punishment, except in the unlikely event that the state can ensure something akin to what Meir Dan-Cohen calls "acoustic separation" in as general a situation as this one. See Meir Dan-Cohen, Decision Rules and Conduct Rules: On Acoustic Separation in Criminal Law, 97 Harv. L. Rev. 625 (1984) (defining "acoustic separation" as a situation in which those who apply rules and those who are subject to them occupy what amount to "different, acoustically sealed chamber[s]"). 
achieved through the crime? In some sense, this is an empirical question; to the extent we are concerned about finding appropriately intense burdens to redress unfair advantages from crime, empirical facts such as the extent of the burdens one suffers from certain types of reputational sanctions are likely to be important. My point in general is that there is nothing in kind about this sort of private burden that makes them obviously unsuitable for punishment. To put this differently, if the state had the means to effect these sorts of punishments (e.g., to emphasize reputational harm instead of imprisonment), nothing inherent in them suggests that they are obviously inappropriate ways to address unfair advantages under a fair-play account.

Of course, we may not trust in the reliability of some kinds of punishments, but this is an empirical, not a theoretical, limitation. Problems relating to proof of such burdens - and opportunities for offenders to strategically manipulate a criminal-justice system that depends on themmay make many of these burdens unsuitable in practice as a way to ensure that an unfair advantage is addressed. But as a matter solely of principle, these punishments should satisfy fair-play theory. ${ }^{25}$

There is perhaps one conceptual problem that follows from a system that acknowledges private burdens that result from crime. Consider crimes such as sexual offenses against children, which cause widespread moral outrage and lead to very strong reputational sanctions. Paradoxically, if we let intense reputational sanctions count as burdens that offset the benefits from crime, then further punishment by the state may become relatively

25. It is interesting to note that at least in principle, private burdens that result from crime ought to be just as relevant to several other accounts of punishment as they are to fair-play theory. I have already identified some reasons this may be true for communicative or expressive theories of punishment. See supra note 2I. It is also true of consequentialist accounts that emphasize deterrence: to the extent that the burdens I discuss in this section are real, and to the extent offenders can expect them ex ante, it makes sense for those burdens to offset official punishment; that is, it makes sense for the state to reduce official punishment (barring such things as administrative concerns) precisely to the degree that the offender has suffered private burdens as a result of her crime.

Of course, private burdens may be less calculable or predictable than official punishment and thereby provide a weaker deterrent. Still, with-say-rampant vigilantism, there might be, from a consequentialist perspective, too much punishment (in terms of instrumental deterrence) under a regime whose official stance is to ignore the possibility of such vigilantism in determining sentences. 
less appropriate in such cases, which seems wrong (or at least counterintuitive) because these cases are precisely those in which the crime was particularly troublesome. Note that this obviously doesn't mean that sentences ought to be lowered from current levels for such crimes; it may be that those who commit particularly troublesome crimes deserve enough punishment to accommodate both the state's severe punishment and the reputational sanctions that private parties impose. Still, it seems odd that violations that lead to widespread outrage should contain within them, thereby, a component that suggests that less official punishment is appropriate. For crimes that are relatively less severe but nonetheless generate similar outrage (say, the possession of child pornography), perhaps this analysis's lesson is that the reputational sanctions that result from conviction alone can impose much of the burden for which fair-play theory calls.

One final elaboration needs to be made about my view. In emphasizing the consequences of offenses and in suggesting that they matter for fair-play theory's view of transactional justice (which is based on crimes and what happens as a result of crimes, but not on prior conditions or unrelated contemporaneous events), I do not mean to suggest that all consequences matter. For fair-play theory's transactional view of crimes, the causal relationship between crimes and the burdens that result from them is an outer limit-a maximum range, not a minimum one. Thus, it should already be clear that a thief who happens to lose money in the stock market after he commits an unrelated crime does not deserve to be punished less because of his stock-market loss (even if the loss were, on its own, somehow unfair). The vandalized vandal, or the robbed robber, deserves no reprieve on account of coincidental harm he suffers. Mere turnabout is not "fair-play." But it might not already be clear that a causal relationship between crime and harm suffered is not sufficient for the harm to matter for a fair-play analysis. Harms that are remote or attributable to other events in most cases should not matter, and in defining the scope of transactions, it is to be expected that familiar (albeit familiarly complicated) notions of proximate causation play a role. So, for example, a prisoner who suffers a deliberate self-inflicted injury in prison may end up suffering more as the "result" of her crime than one who does not (that is, if all consequences of the crime matter, however remote or otherwise attributable). But few would regard this injury as a reason for reducing the prisoner's sentence. 


\section{Applications to Cases and Some Puzzles in Criminal Theory}

Some criminal-law instructors ask students hypothetically whether wrongful punishment by the state should entitle offenders to a "free crime" in the future. ${ }^{26} \mathrm{I}$ take this question to test students' intuitions about the interplay between transactional and nontransactional justice; the question is difficult to the extent that those intuitions are in conflict. My analysis suggests the answer to the question is that no "free crime" is warranted because the punishment was not effected in response to, or as a result of, the crime.

Compare the situation where someone is wrongly punished to a situation Christopher New has discussed-the hypothetical opportunity to punish someone for a crime before she commits it. ${ }^{27}$ Note that in New's situation, we are still punishing for a crime-that is, in some sense in response to and as a result of it. If we can imagine causation (between crime and punishment) running backwards in time, as it would appear to do in a world where we could see the furure, then I see no problem with New's defense of pre-punishment. At least, it does not violate fair-play theory's constraints.

Interesting variations on these situations are possible and help test my analysis. For instance, consider the wrongful punishment of an individual as the result of a mistake by the state, followed by an official determination of the individual's innocence for the crime punished, followed in turn by a separate determination of guilt for a different (past) crime that carries the same sentence as the original punishment. Does causation between crime and punishment matter here too, or does the wrongful state punishment somehow cancel out the justice of further state punishment? Note that there is no direct consequentialist danger here, as there is in the "free crime" situation; in this case, we are not contemplating giving anyone a "free crime" to commit in the future, for the crime we're considering punishing is already in the past. The only question is whether wrongful but unrelated punishment eliminates desert. My analysis suggests that the wrongful punishment that isn't causally related to the offender's particular crime, while of course regrettable and subject to a debate about appropriate remedies, does not eliminate the offender's desert for an

26. See, e.g., Peter Westen, Course Materials for "Problems in Criminal Law Theory," Week 5, Question 6 (2004) (on file with author).

27. Christopher New, Time and Punishment, 52 Analysis 35 (1992). 
unrelated crime-that is, does not render unrelated punishment unjust. Situations like this may reflect particularly compelling cases for mercy (in the form of prosecutorial discretion or pardon), where mercy is conceived as a way to avoid the harshness of transactional justice. But if the fact that one unjustly suffered at the hand of the state on an unrelated charge is important when determining desert for a crime, then we have adopted a view so nontransactional that it is hard to rule out the consideration of other unrelated hardships the offender has suffered (particularly at the hand of the state) in considering the justice of punishment.

Interestingly, courts that have considered the question have reached results consistent with this reasoning, though typically in an undertheorized fashion. $^{28}$

28. See Holscher v. Young, 440 F.2d I283, 1290 (8th Cir. 1971) ("Due process does not require that Holscher be credited with the time spent in prison under the prior illegal conviction of a crime unrelated to the present case. Holscher relies on the case of Hill $v$. Holman, 255 F. Supp. 924 (M.D. Ala. 1966), but despite the broad language used in that opinion, the credit for time served which was allowed in that case was for time spent in prison under a prior illegal sentence, against a sentence later imposed for the same crime."); United States ex rel. Watson v. Commonwealth \& Common Pleas Court, 260 F. Supp. 474, 475 (D. Pa. 1966) ("[W]e cannot conceive of a constitutionally mandated system of accumulated prison credits. Other courts have concurred in our incredulity. Such a requirement of credit for time served under vacated sentences would enable recidivists to obtain release or to avoid incarceration altogether by the simple device of pleading a prior invalid imprisonment. Even in those cases where a sentence is vacated and the relator is re-tried for the very same offense, there is no constitutional requirement of credit for the time already served." (citations omitted)); State v. Calderon, 66I P.2d 781, 789 (Kan. 1983) ("[Under statute, a] criminal defendant sentenced to incarceration [must] be given credit for all time spent in custody solely on the charge for which he is being sentenced.").

In discretionary sentencing (which again may reflect mercy in addition to justice), courts have occasionally been willing to consider prior harsh but officially nonpunitive treatment at the hands of the state, even on distinct charges. See, e.g., Kirk Semple, Padilla Gets 17-Year Term for Role in Conspiracy, N.Y. Times, Jan. 28, 2008, at Ar4 ("Over prosecutors' objections, Judge Cooke gave Mr. Padilla credit for the three and a half years he spent in a naval brig in South Carolina after his arrest in 2002 on suspicion of being involved in the dirty bomb plot, accusations that were dropped. In detention, Mr. Padilla underwent prolonged isolation and intensive interrogations in conditions the judge called 'harsh.' The conditions, she said, 'warrant consideration in the sentencing.'"). The correct treatment of Padilla's sentence (as a matter of justice, not mercy) depends, under my analysis, on how related the dropped charges were to the charges for which he was convicted and sentenced. 


\section{LOST BENEFITS}

Recall that under Morris's fair-play account of retributivism, punishment is meant to address an imbalance between burdens and benefits. Part II identified situations in which the imbalance was redressed by burdens other than formal punishment imposed by the state. But to the extent an offender deserves punishment because he "owes something to others, for he has something that does not rightfully belong to him,"29 we can also ask whether punishment is just when this "something" is lost before punishment is imposed.

To do this, we need to review the kinds of unfair benefits criminal offenders might receive. The type of benefit appropriate to a fair-play analysis is unsettled, but a few broad contours are —or at least should be-clear.

First, just as with burdens, ${ }^{30}$ the benefits with which the fair-play account is concerned must proceed causally from the crime. Thus, for instance, it is not necessarily correct that "if a businessman has secured a contract worth $\$ 100,000$, but has exceeded the speed limit in order to get to the relevant appointment on time, he should presumably be fined $\$ 100,000 .{ }^{31}$ In that case, the crime is not necessarily a cause-and is certainly not the sole cause - of the profit the businessman received..$^{32}$ Even when a gain happens to follow a crime, the offender might still have realized the gain without breaking the law, and the offense may have contributed in only a minor way to the gain. Fair-play theory, accordingly, does not necessarily justify full disgorgement of gains that simply follow a crime.

29. Morris, supra note 7 , at 478 .

30. Cf. supra note ro and accompanying text.

3I. John L. Mackie, Retribution: A Test Case for Ethical Objectivity, in Philosophy of Law 667 (Joel Feinberg \& Hyman Gross eds., 1991).

32. Cf. E. Allan Farnsworth, Your Loss or My Gain? The Dilemma of the Disgorgement Principle in Breach of Contract, 94 Yale L.J. 1339 (1985) (arguing that contract law should not require those who breach contracts to disgorge their full gains because the breach may not be a "but for" cause, and is often only a joint cause, of breaching promisors' gains). Farnsworth also discusses what he calls "remote cause"-a cause far away (typically in time) from its result. We might imagine an offender who is able to achieve his goals only because of the mental satisfaction that he gets from having commitred a crime many years earlier; it is nonetheless hard to say that all the offender's achievements are relevantly a benefit from the crime. 
Second, the relevant benefits under the fair-play account need not be objectively verifiable, concrete, financial, or transferable. The example of the speeding businessman above suggests wrongly that the "benefit" from speeding - or perhaps from a crime in general-is identical to the financial surplus that accrues to the offender; indeed, John Mackie, who provided the example of the businessman, seems to make this view explicit by arguing that under a fair-play view, "a fine of $\$$ I would be enough for someone who murders a blind cripple to rob him of $\$$ I. . . . Unsuccessful attempts ... should not be punished at all." ${ }^{33}$ If benefits from crime were simply financial (or other sorts of zero-sum transfers from the victim to the offender), then an analysis of lost benefits would be extremely straightforward: any reversal of this zero-sum transfer would make further punishment unjust. Of course, however, not all benefits are financial, and the presence of financial benefits does not exclude the presence of other benefits; indeed, one who murders a blind man to steal a dollar from him has committed both murder and robbery. More generally, the gain to an offender does not necessarily or even usually equal the loss to the victim, which explains (among other things) why it is not necessarily inappropriate to punish unsuccessful attempts.

Beyond these two broad principles, commentators disagree about precisely what kind of benefits give fair-play analysis the most appropriate scope. Morris's account, by its own terms, treats the relevant benefit as that derived from a system in which everyone complies with laws. ${ }^{34}$ In fact, Morris's account does not directly set off the burdens from punishment against the benefits received from crime; instead, it seems to intend for the burdens from punishment to replace the burdens that the offender has renounced. ${ }^{35}$

Nonetheless, the general form of Morris's argument is consistent with numerous types of "benefits"- beyond those the crime literally transfers from the victim to the offender, if it indeed transfers anything-that accrue to offenders as the result of their crimes. Richard Burgh lists two

33. Mackie, supra note 31 .

34. See Morris, supra note 7 , at $477-78$.

35. Perhaps a cleaner way of stating this view is that the relevant benefit from crime is the offender's renunciation of a burden on his action. Cf. Ten, supra note 6 , at 55 (using similar language and describing the relevant benefit from crime as "the voluntary renunciation of the burden of restraining oneself from violating the law"). I elaborate this view of benefits further infra under the rubric of "appropriation of excess freedom." 
possible such benefits: the subjective (hedonic) enjoyment by the offender at having committed the crime, and the appropriation by the offender of "a bit more freedom than others."

Though Burgh does not disaggregate the former of these factors into its component parts, it seems that the relevant kind of enjoyment may include several features. First, offenders may enjoy the material benefits that come from committing the crime-for instance, they may enjoy the money from robbery or the satisfaction of whatever motive drove them to kill. Second, they may enjoy committing crimes; this may be because of the nature of the crimes themselves, or it might come from the thrill of committing a criminal act because it is a criminal act. ${ }^{37}$ Third, offenders may take satisfaction from the memory of their crimes. This memory itself may take several forms: memory of the spoils and memory of the activity are the most obvious, but a more subtle and potentially more significant satisfaction may arise from getting away with a crime-from the recognition that one has broken the rules without being held to account for them in any way. ${ }^{38}$ In all these cases, the existence of a benefit is a question of psychological fact, of the kind that might be addressable by a sufficiently sophisticated neural scan. ${ }^{39}$

36. Burgh, supra note 6, at 203.

37. This sort of satisfaction may be associated with the psychology of "thrill seeking," thought by some to help explain the rates of adolescent crime. See, e.g., Commentary, Thrill and Adventure Secking and the Age Distribution of Crime, 90 Am. J. Soc. 1326 (1985).

38. Cf. Thomas Morawetz, Adam, Eve, and Emma, On Criminal Responsibility and Moral Wisdom, 22 Quinnipiac L. Rev. 23, 28 (2004) (suggesting the gain from crime can be "even just the satisfaction of having broken a rule"). I associate this sort of satisfaction with the characteristic ancient Greek philosophers called $\pi \lambda \varepsilon o v \varepsilon \xi i \alpha$ (pleonexia) roughly greed or coverousness. Pleonexia is generally taken to be the opposite of the senti-

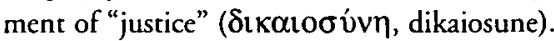

39. In discussing psychological benefits, I don't mean to imply that they are frequently experienced by all kinds of offenders, nor am I making any positive claims about criminal psychology. My goal is simply to consider possible benefits so that my temporal analysis addresses them.

Also, in suggesting that a sophisticated neural scan might answer questions of psychological fact, I don't mean to assume that this is true or to discount puzzles in determining the nature of psychological benefits in all their multiplicity. Cf. Mark Kelman, Hedonic Psychology, Political Theory, and Law: Is Welfarism Possible?, 52 Buff. L. Rev. I (2004) (discussing these puzzles in detail). 
The latter of Burgh's factors - the appropriation of excess freedom-is more difficult to analyze. David Dolinko has criticized its simple formulation by noting that the offender appropriated no freedom that he didn't already have- and indeed, that others have the same freedom even though they don't commit crimes. ${ }^{40}$ But the force of this objection is unclear. It is true that offenders and nonoffenders are equally "free" to commit crimes in a technical sense that conceives "freedom" as the physical potential to act; that is, the answer to the counterfactual question "Could one have physically acted in violation of the law?" is likely to be "yes" even for many nonoffenders. But the relevance of this counterfactual question is unclear; in point of fact, offenders act freely with respect to the violated rule whereas nonoffenders do not. Many commentators seem to have this observation in mind when they discuss the benefits offenders receive from crime; for instance, as I noted briefly earlier, ${ }^{41}$ C.L. Ten refers to "the voluntary renunciation of the burden of restraining oneself from violating the law" and notes that other commentators have used similar language, such as indulging one's will or exercising self-will. ${ }^{42}$ (For Ten, "punishment removes the offender's advantage of freely indulging his or her will or of renouncing self-restraint." $)^{43}$ In a short essay to which I will return, John Finnis specifically considers when offenders benefit from their crimes-a question that is particularly relevant for my analysis-but before doing this, he suggests that the relevant benefit from crime is "the advantage of indulging a (wrongful) self-preference, of permitting [oneself] an excessive freedom in choosing." 44

My goal here is not to identify the particular benefit from crime that best justifies fair-play retributivism. At this stage, it is important only to note that all of these benefits I have discussed so far seem potentially

40. See David Dolinko, Some Thoughts About Retributivism, Ior Ethics 537, 547 (1991) ("In what way does the lawbreaker 'gain' this freedom? In one sense, the lawbreaker has perhaps revealed that he has a kind of 'freedom' by exercising it-by demonstrating that he is able to violate the prohibition. In this sense, however, he must have been 'free' from the prohibition even before his lawless act (or he could not have committed it!) . ...").

41. See supra note 35 .

42. Ten, supra note 6 , at 55 .

43. Id.

44. Finnis, supra note 22, at 132. Compare "wrongful self-preference" with the psychological enjoyment of "getring away with crime" that I discussed in supra note 38 and accompanying text. 
important: a fair-play account that fails to justify punishment when an offender receives any of these benefits may turn out to represent only a partial account of the reasons for punishment. Accordingly, since this section describes several situations in which punishment may be unjust because the offender may have nor received-or may no longer retain-a benefit from her crime, I will discuss whether any of the potentially relevant benefits is present in the situations I describe. That is, my goal is to put forth an argument that temporally evaluates each of these-and perhaps otherviews of benefits.

Note, however, that under none of these views of relevant benefits does the harm to the victim matter directly; offenders may be fairly punished for crimes that result in no harm (such as attempts), and many actions causing great harm do not give rise to any offender to punish. As C.L. Ten has noted, offenders may well owe compensation to victims as a result of the distributional inequity to the victim that the crime caused, but fair-play theory posits a separate distributional inequity between the offender and society at large, and punishment is designed to address this latter imbalance. ${ }^{45}$

This section proceeds by describing two broad classes of situations in which punishment may be unjust because the inequity associated with crime is no longer present by the time punishment is possible. There is not a sharp conceptual distinction between these classes, but for ease of exposition, it may help to separate them somewhat. In the first kind of situation ("reversible crimes"), the offender may be able, through her actions, to avoid accruing any benefit from her offense, thereby reversing whatever unjust distribution the offense might have otherwise entailed. In the second kind of situation ("lost benefits"), the passage of time and the change in the offender's character causes the offender either to lose the benefit she once received from the crime or no longer to relate to that benefit in a way that justifies punishment. In these situations, though offenders may once have drawn a benefit, it is no longer present or no longer worth addressing, so there is no unjust distribution worth remedying.

\section{A. Reversible Crimes}

Perhaps surprisingly, when we pay attention to the nature of the benefits offenders receive from crime, we find that there may be less reason than

45. See Ten, supra note 6, at $54-55$. 
courts and commentators typically suppose for crimes to be treated as irreversible - that is, as "complete" at a particular point in time and unable to be undone later. ${ }^{46}$ Though considerations of policy may warrant bright-line rules regarding crimes' completion (in view of such factors as administrative costs, general deterrence, and character-based theories of liability), such rules are not required by (and, depending on the relevant benefit from crimes, might not even be justifiable under) a fair-play retributivist perspective. Others have made roughly similar points; for instance, in a thoughtful article on abandonment of attempts, Paul Hoeber suggests that a dependence on what the law traditionally conceived as a "complete" crime is formalistic, and we should instead consult our purposes in criminalizing conduct to determine what constitutes a "complete" crime. As Hoeber says nicely, a crime "is complete when we say it is."

My argument in this section is more general: it may be formalistic even to imagine (from a fair-play perspective) that crimes are ever necessarily "complete"-that they all, definitionally, include a time after which the offender cannot undo the crime by subsequent actions. If what matters in justifying punishment is the benefit from crime, then the loss of the benefit removes the justification of punishment, regardless of when it was lost. Of course, a transactional view of justice may prevent us from considering some ways benefits might be lost, but if we are concerned with what results from criminal conduct, we have no reason not at least to consider the whole course of the conduct. I do not mean to suggest that the fair-play view never allows for bright-line rules concerning the completion of crimes (to be introduced into criminal law for reasons that have nothing to do with fair-play analysis), only that it does not require them itself and that it suggests that they are unjust under some conditions.

The basic argument for this view is simple. To begin with, the concept of a benefit from crime does not logically entail that the offender cannot,

46. For sources showing that courts and commentators take this for granted, see Paul R. Hoeber, The Abandonment Defense to Criminal Attempt and Other Problems of Temporal Individuation, 74 Cal. L. Rev. 377, 378 n.I (1986) (collecting treatises and similar sources); cf. Model Penal Code $\$$ I.or (Proposed Official Draft 1962) (for purposes of statutes of limitations, crimes are "committed either when every element occurs, or, if a legislative purpose to prohibit a continuing course of conduct plainly appears, at the time when the course of conduct or the defendant's complicity therein is terminated").

47. Hoeber, supra note 46 , at 378 . 
through her actions, eliminate the benefit after receiving it. Nothing requires that one who once received a benefit continue to retain it. Whether a benefit will persist through time depends both on the nature of what we mean by "benefits" (that is, which benefits we decide are relevant) and on natural facts.

If we were creatures with no memory, for instance, we would likelyon reflection, if reflection were possible without memory-determine that the prior experience of a benefit that left no other mark on the world would likely be an insufficient justification for fair-play punishment, even if the benefit were achieved unfairly. We may well want to prevent such unfairness in the future and impose instrumentally protective measures, but backward-looking punishment seems inapposite for stateless entities in a stateless world because, without the preservation of state, there remains no inequitable distribution to redress. ${ }^{48} \mathrm{~A}$ transactional explanation of punishment that is distributional in nature necessarily incorporates a sensitivity to changes in state; without the possibility for such changes, the justification for punishment collapses.

It is perhaps natural to try to explain this conclusion by drawing a distinction between the "identity" of one who once experienced a benefit and the person who now exists without any memory of such a benefit. ${ }^{49}$ But even though identification of the offender with a present person is probably a necessary condition for fair-play punishment, it is not sufficient. As a general matter, it is hard to see how the mere historical existence of an unfair benefit is enough to justify present punishment if we agree that the benefit is no longer present. If benefits can be lost even though identity between the historical offender and a present person remains-as certainly is logically possible-it is not clear what the moral purpose or justification of punishment would be under a fair-play account.

The question, then, is whether a person who once experienced the kind of "benefit" that matters for fair-play retributivism may in fact lose this benefit. Certainly, the "unfair advantage" with which Morris is concerned can exist at one point in time but not exist at a later point in time; in fact, punishment itself makes this possible. But in cases of punishment, the unfair

48. To make this example more (potentially) relevant, consider an offender who, using science-fictional, brain-altering drugs, removes all memory of a particular crime (and everything related to it) and retains no other benefit from it.

49. Cf. text accompanying infra notes $65-66$. 
advantage is lost through a burden. By contrast, the particular question with which this section is concerned is whether the unfair advantage might be lost because the benefit is lost through the offender's actions. Accordingly, this section considers in more detail the various types of benefits that may be relevant to retributivism in view of some patterns of factual situations.

\section{Material Benefits}

Though it is hardly worth mentioning, the view that a crime's only benefit is the material spoils transferred from the victim to the offender would seem to suggest that a return of this benefit is enough to remove the unfair advantage from the crime. To put this differently, if benefits from crime were only financial or material, then-aside from the (significant) problems associated with imprisoning only the poor while letting the rich pay off their debts to society financially-there would be no fair-play justification for punishing anyone for a crime whose victim the offender had made whole financially or materially. If crime is conceived simply as a forced zero-sum transfer from the victim to the offender, then many crimes could be undone, at least for solvent offenders, by a reversal of this transfer. ${ }^{50}$

If this view of crime were correct, then a crime need never be "complete." For example, punishment would become unjust, even in the middle of a prison sentence, if the offender were able to compensate the victim successfully. It would not matter that the offender had engaged in the crime, had passed up opportunities to reverse the crime's effects before detection, and so forth. The justification for punishment would evaporate as soon as compensation were complete.

5o. Mark Reiff, in an extended argument about the relationship between punishment and compensation, seems to adopt the view that punishment is a form of compensation; he takes to its logical conclusion the view that the benefits from crime always equal the costs to the victim and suggests that punishment should only make up what compensation can't. Mark R. Reiff, Punishment, Compensation, and Law: A Theory of Enforceability I33 (2005) ("When full compensation is not only available for the beneficiary's injuries but also actually paid, the beneficiary will by definition be made indifferent to the violation, and no retributive punishment would be due."). Of course, Reiff does not suggest that compensation is always available or that it will in fact always be paid-but he does, through at least part of his argument, equate "benefit from the crime" with "burden to the victim." See id. at 133-34. 
Though I have spoken of compensation, it is worth keeping in mind that though compensation may fairly be required of an offender because of the unfair distribution her crime created vis-à-vis the victim, punishment at the hands of the state addresses a different unfair distribution. As a result, on the view that the only relevant benefits from crime are the material gains from the crime, any loss of this material benefit would be enough to undermine the justice of punishment. An offender who steals $\$ 200$ and then loses it immediately thereafter (or indeed at any point thereafter but before punishment) would, for example, probably not deserve punishment if this view were correct.

The precise characteristics of "loss of a material benefit" are interesting to consider. Suppose, for instance, that an offender steals a sum of money and immediately gambles it away at a casino, losing it all. The offender received a benefit in the form of a chance, and because he was not entitled to this chance-which certainly had a value $e x$ ante-his exercise of it was unfair. ${ }^{51}$ Nonetheless, on a view that the only benefits that matter from a crime are its material ones, it is not clear that the losing gambler retains anything from the crime. What of an offender who buys, with the spoils of crime, perishable goods or services that do not have a lasting effect on the material position of the purchaser? Presumably, the offender enjoyed the goods and services, but they no longer remain, and without incorporating some recognition of the psychological (or other) benefits from the crime, it is not clear that the offender who buys such goods or services retains anything material from it. ${ }^{52}$

5I. Cf. Harris v. Time, 237 Cal. Rptr. 584, 587 (Cal. Ct. App. 1987) (treating an increase in ex ante probability as "valuable consideration" in contract law).

52. In fairness, one who focuses only on material benefits need not adhere to such a strict view. For one thing, those who focus on material benefits may not be interested in benefits at all, except as a proxy for the loss to the victim. As I have suggested, however, it is not clear that commentators with such a focus hold a view consistent with the fair-play view of retributivism, which centers on offenders, not victims.

Still, the strict material-only view that I've discussed in the text can perhaps be tempered by a more thorough account of chances and probabilities. For instance, one might adopt the view that the only relevant benefit from financial crimes is the improved probabilistic position of the offender, irrespective of whether any material benefit now remains from this improved probabilistic position. A gambler who steals Ioo chances at a game and wins on one of them would, on this view, have beneficed from all the chances, rather than just from the one on which she won. That is, an offender can misappropriate a chancesomething with a particular expected value-and any events subsequent to this reflect 
Now, in some sense, this reduction to the absurd shows the unhelpfulness of a view of crime that recognizes only benefirs that are strictly material. But in another sense, there is at least some difference between an offender who retains the material spoils of a crime and one who doesn't. Claudius's lament, with which I began this article, suggests that one who retains the spoils of a crime is in a particularly poor position to ask for mercy, to begin to repent, or-more relevantly for our purposes in this section-to claim that a crime was not committed or that no unfair distribution of burdens and benefits has resulted from it. The desire to retain material benefits may also serve as evidence of other more complicated benefits, such as psychological benefits, that the offender retains. But a view of crime that conditions the justice of punishment on the retention of physical spoils is obviously incomplete.

\section{Psychological Benefits}

Recall that I divided psychological benefits into three categories: (I) enjoyment of the material benefits from the crime; (2) enjoyment of criminal activity itself; and (3) memory that results from the crime, including potentially the satisfaction at having "gotten away" with it without being held to account. For the first of these categories, the analysis tracks that of

simply the normal workings of the market and not anything related to the crime. An offender who loses $\$ 200$ that he just stole thus has nor lost the full financial benefit from the crime. In committing the crime, the offender was of course taking a chance (though not necessarily consciously) that he might lose the money he stole; one takes this chance whenever one possesses currency. The material benefit from this crime was this chance, and the offender successfully appropriated it. Punishment is imposed to counteract the benefit associated with the chance. (Again, the offender might owe the victim restitution, but fairplay punishment does not aim to address the inequitable distribution between the offender and the victim specifically.)

The problem with this view is that it is hard to understand what morivates it other than a broader conception of the potential benefits from crime. In order to retributively punish the misappropriation of chances that have been lost by the time of punishment, we need to believe that the offender retains some benefit from these chances. This benefit is not, strictly speaking, material; it does not physically remain at the time of punishment. Instead, it corresponds to something else the offender has but shouldn't have-the enjoyment of the bet, or the appropriation of freedom, or the indulgence of will, or the notion that it was unfair for the offender to have had the illicit chance in the first place, even though it did not pan out. Accordingly, I do not treat this view separately; instead, it can be folded into my discussion of psychological and more ethereal benefits. 
material benefits: once they are gone, their enjoyment is gone. Similarly, any enjoyment of criminal activity itself ends when the criminal activity ends.

This third category of benefit-memory-is accordingly the most significant one for our purposes in the case where the offender is no longer able directly to enjoy the spoils of the crime (and I take this to be the typical case where an offender is apprehended and convicted). Focusing on the third category suggests that punishment is justified because it aims to prevent offenders from enjoying the memory of their crime, the memory of its spoils, and-perhaps more importantly-the satisfaction that they could otherwise have "gotten away" with illicit action. This view is plausible to me as reflecting at least one type of important possible benefit from crime, for it seems intolerably unjust to allow people to exploit society in this manner-to gloat, even privately, about their criminal successes. To put this differently, a retributive view that removes the opportunity for this kind of satisfaction seems particularly plausible to me as a justification for punishment.

Consider, then, the view that punishment is just under a fair-play account when the sort of psychological enjoyment that falls under my third category remains. Under this view, the justice of punishment may still be questionable in some siruations where it is currently considered unproblematic.

For example, consider cases in which the offender immediately tries to undo his crime - the theft of a physical object, say, followed by its immediate return. ${ }^{53}$ In these situations, the offender retains no spoils from the crime and probably never enjoyed the benefit of any such spoils. He may have enjoyed committing the crime, and indeed, if the state does not punish him for his actions, he may enjoy the fact that he was able temporarily to transgress without being held to account. But the offender seems unlikely to experience this sort of enjoyment to any significant degree; instead, it is more likely that the offender thought twice about the crime and decided not to let it proceed. (Particularly if the offender's reversal was morivated by remorse or a similar feeling, the enjoyment of the crime following the reversal is likely to be exceedingly minor, if present at all.) Importantly, the offender has accounted for the crime in an important way, so the satisfaction from having committed a crime without being held to account is not likely to be present. 
Indeed, if we emphasize psychological benefits from crime (as opposed to the more ethereal freedoms associated with it), it is hard to meaningfully distinguish larceny followed by the immediate return of stolen goods, one on hand, from an abandoned attempt, on the other. ${ }^{54}$ Indeed, the view that a larceny is necessarily complete at a particular point in time resembles the sort of formal "asportation" and "caption" requirements that the Model Penal Code attempted to eliminate. ${ }^{55}$ I don't mean to suggest that there can't be sound policies in support of bright-line rules governing the completion of crimes; as I mentioned at the outset, it might be easier to administer a system of criminal justice that defines offenses with clear temporal boundaries, and such policies may promote general deterrence (and thereby public safety) by encouraging offenders to consider their actions in advance-particularly because many crimes are indeed irreversible in fact. Moreover, there may be moral reasons such a requirement is warranted. In particular, completing a larceny (or other crime) demonstrates something about the offender's character; the offender was willing to act criminally. But reversing a crime such as larceny, particularly under the same sort of circumstances that would satisfy the law of abandonment of attempts, ${ }^{56}$ seems to foreclose the possibility that the offender will experience the most important sorts of psychological benefits that can flow from crime. As a result, punishment in such cases is questionable under a fairplay view that emphasizes psychological benefits. ${ }^{57}$

54. Note that even some kinds of abandoned attempts raise problems for those who are committed to the view that a crime must have a particular "point of no return" tied to the crime's formal elements. See generally Hoeber, supra note 46 (refuring such a strict interpretation of abandonment).

55. Model Penal Code $\$ 223.2$ (Proposed Official Draft 1962).

56. I refer in particular to the sort of circumstances that would amount to "a complete and voluntary renunciation of . . c criminal purpose" under Model Penal Code $\$$ 5.0I(4) (Proposed Official Draft 1962).

57. Some consequentialist analyses might share the conclusions of a fair-play retributivist approach in situations where a crime is abandoned after the fact: just as with abandonment of attemprs, offenders who try to reverse a crime shortly after commitring it prove themselves to be less dangerous to society than those who don't. Moreover, there is little reason to try to deter crimes that are successfully "reversed" from the victim's perspective, as long as the reversal is complete. It is also important to note that a rule that does not reduce punishment in response to the "reversal" of a completed crime provides little incentive for offenders to seek to reverse their crimes once they are complete. But see Hoeber, supra note 46 , at 398 (arguing in the context of abandonment of attempts that 


\section{3. "Freedom" and Other Ethereal Benefits}

The less tangible benefits-those associated with freedom, the renunciation of self-restraint, unfair self-preference, and so forth-pose difficult questions about the justice of punishment in cases where the offender does not retain other kinds of benefits. For one thing, it is harder to offset tangible punishment against intangible benefits such as "unfair self-preference" than against tangible enjoyment of crime; such an offset is bound to lead to questions about how, exactly, suffering restores fair balance. It is one thing to impose hard treatment to prevent a subjective enjoyment that we find intolerable; it is another to use it to redress something wholly abstract. I don't intend to dwell on these problems, and I don't think they are necessarily insurmountable; indeed, to the extent that unfair "freedom" is our concern, our society's emphasis on imprisonment as punishment may, at least in theory, be particularly appropriate, not for the suffering it causes but for the limitations on freedom it imposes. ${ }^{58}$ At any rate, I just mean to nod toward these problems; addressing them is beyond my scope here.

The central question I want to raise for fair-play accounts that depend on "freedom" and similar benefits is the following: to what extent does the past experience of this sort of freedom matter when it is no longer exercised? John Finnis aims to address this question in a short essay in which, among other things, he adopts the view that the relevant benefit from crime is "the advantage of indulging a (wrongful) self-preference" and asserts that this benefit "is gained at the time of the crime, because and insofar as the crime is ... a free and 'responsible' exercise of self-will; the wrongfulness of gaining this advantage is the specifically relevant moral turpitude adverted to in the retributivist's talk of criminal 'guilt'; and the advantage is one that cannor be lost" except through punishment imposed

\footnotetext{
"knowledge of the defense [may] also encourage people to make attempts they would not otherwise make, and if not all such atrempts will be abandoned, then the number of these encouraged attempters might equal or exceed the number of attempters who abandon because of the defense").

58. Compare this observation with Finnis, supra note 22, at 133 (noting that what is important about punishment is "not, formally speaking, ... infliction of pain (nor . . . incarceration), but rather . . . the subjection of will (normally, but not necessarily, effected through the denial of benefits and advantages of social living: compulsory employment on some useful work which the criminal would not of himself have chosen to do would satisfy the definition)").
} 
by sociery.9 To support this latter assertion, however, Finnis marshals little more than a corresponding assertion by Aquinas that an offender is "worthy of punishment ... in so far as he violates the order of justice.... He does not return to that order except by way of some sort of punitive recompense . . . " ${ }^{60}$ As far as I can determine, the best argument for this position is that a criminal offender unfairly disadvantages those who try "to live in strict accordance" with the law; ${ }^{01}$ accordingly, as soon as an offender commits a crime, she has taken something she doesn't deserve, and punishment is the only way to restore a fair balance.

Of course, such a statement is likely too strong in any event; as Morris and others have noted, the possibility of forgiveness and pardon suggests that punishment is not the only way an unfair balance that results from a crime can be restored. ${ }^{62}$ But more importantly, it is not even clear what motivates the weaker position that the offender cannot through her own actions restore equity, particularly if the aim of such a position is to argue for (rather than merely to defend punishment given the existence of) bright-line rules that define crimes in terms of their simple elements and do not allow for subsequent abandonment. To elaborate this point, there is a distinction between (I) a view that the fairplay account entails that crimes ought to be defined such that they contain clear "points of no return" and that these points in time should not depend on such things as the offender's opportunity to try to reverse the crime, and (2) a view that punishment is just when society has defined crimes in this way for other reasons. The first claim is extremely strong, and I cannot discern any justification for it; it is not clear why fair-play retributivism demands this kind of definition for crimes. The second claim, on the other hand, may well be correct-as long as we decide that the relevant benefits from crime include the sort of "unfair freedom" on which this section focuses. This is because, given a definition of crime with other motivations (such as administrative concerns), there is a range of activity in which law-abiding citizens do not engage, and society benefits as a result. Offenders, on the other hand, do engage in this activity. As long as the law defining the crime is not unjust for other

59. Id. at 132-33.

6o. Id. at 134 .

6I. Id.

62. See Morris, supra note 7 , at 478 ; Matravers, supra note 7 , at 57 . 
reasons, the offenders' behavior may be unfair. ${ }^{63}$ Even if substantive rules make some offenses instantaneous and irrevocable solely for administrative reasons, there is a sense in which it seems unfair for offenders to gain the benefits that result from such administrative decisions and yet to fail to apply those decisions to themselves.

Even so, there seems to be a meaningful difference between an offender who tries to reverse a reversible crime-say, before detection by criminal authorities - and one who does not. The former may have renounced a degree of self-restraint unfairly, but she then reimposed this restraint upon herself-the same sort of restraint, or at least a very similar one, that nonoffenders impose on themselves. She may have exercised freedom unfairly, but she then took steps to give up this very freedom. In what other context is "fairness" so inflexible a concept that it does not permit immediate reversal of unfair actions? Would we say that someone who cheats off a friend on a multiple-choice exam in school, but then restores his answers to what they were before the cheating, has acted "unfairly" or retains an "unfair advantage" with respect to the rest of the world?

\section{B. Lost Benefits from "Completed" Crimes}

Even assuming that there is a reason to treat crimes as irreversible-or, alternatively, even if an offender does not in fact reverse a particular crimethere is another way offenders may lose the benefits they obtain from

63. As a matter of substantive criminal policy, it is not clear to me that administrative concerns militate strongly toward bright-line "points of no return." Crimes could sensibly be prosecuted without reference to a particular point at which the offender crossed a line. Why, then, does our law seem to have an unshakeable notion that there must be such a point? A partial answer may be that many of the most salient crimes are indeed irreversible, in both the lay sense and in the impossibility of an offender's taking any action subsequent to the crime that intentionally eliminates the benefit the offender has received from it. Most obviously, murders cannot be undone. The same is true of most violent crimes against people, for though they may lack the physical permanence of murder, violent crimes often have psychological consequences that cannot immediately be removed.

Another possible explanation is that crimes must be defined with formal points of completion in order to limit the state's discretion-that for reasons of liberty, people must have assurances that they will not be prosecured for lawful activities. But if that is the case, bright-line rules regarding crimes' completion could still exist to rule out criminal prosecution in some cases, rather than to rule in certain activities as offenses. 
crimes. In the cases I described in the previous section, I imaginedthough it is not necessarily so-that any chance the offender has to forgo the benefits of her crime arises shortly after the crime occurred. It is of course possible that an offender might escape detection for many years and might retain the opportunity to eliminate benefits before punishment but long after the crime was committed, but I imagine the archerypal case from the previous section to concern relatively short intervals of time.

By contrast, the archetypal cases for this section concern relatively long intervals of time-intervals over which the offender comes no longer to identify with the benefit she received from her crime. In such cases, some benefits from the crime may no longer remain, though nothing other than the offender has changed; in others, even though benefits may remain, they may simply not be relevant to the offender or to society in a way that justifies punishment. This section's analysis may help explain criminal statutes of limitations.

\section{Benefits That Are No Longer Present, or Present in Only Weakened Form, After the Passage of Time}

As I suggested earlier, it is easy for material benefits (and their psychological enjoyment) to be lost: money is spent, tangible goods wear down, and the benefit from services fades. As time passes, it becomes less likely that an offender retains any spoils from a crime. Indeed, even the memory of crime (and its possible enjoyment) fades over time.

Accordingly, a view that focuses either on spoils or on an offender's psychological enjoyment will likely need to be circumspect about punishing offenders in the distant future following their crime. Is it likely that thirty years after a small theft, for instance, the thief retains any noticeable financial or psychological benefit from the crime?

Consider first the simplest view of benefits-those of material spoils and their enjoyment. Suppose that, as we did before, we draw a distinction between ( $\mathrm{I}$ ) the case in which an offender steals money and saves it and (2) the case in which an offender steals money and spends it on a perishable good or service (the latter eliminating "material spoils" from a crime in the strictest sense, along with the enjoyment of such spoils). Even if we draw this distinction in theory, long intervals likely destroy the possibility of distinguishing between these two cases in fact. For instance, thirty years after a small amount of money is stolen, we are unlikely to be 
able to trace the particular "money" that the offender stole and thereby demonstrate a causal relationship between the crime and the offender's financial position (or enjoyment of it). To put this differently, it is hard to imagine a case where an offender steals a small sum but segregates it from the rest of her funds so scrupulously that it is possible to be confident, thirty years later, that she retains any specific benefit from those funds. Of course, if we could be confident about this benefit's persistence, punishment would not be unjust on this count; the evidence would demonstrate that the long interval between crime and punishment simply didn't matter. But such cases are probably uncommon, and their rarity may help justify statutes of limitations. ${ }^{64}$

Consider next the view of benefits that includes, in various forms, the enjoyment of the memory of a crime and its consequences. After extremely long intervals, it seems unlikely that this enjoyment will be intense or even significant. Of course, there will be exceptions; time does not change all reactions or emotions that people experience in response to events. But as a general matter, we should recognize that the benefits associated with the enjoyment of a crime's memory, including the satisfaction at having gotten away with it, are likely to decrease substantially over time. This fading, too, may help explain statutes of limitations.

\section{Benefits That Are No Longer Relevant After the Passage of Time}

Finally, consider the more abstract benefits associated with unfair appropriation of freedom. These are not susceptible to the same form of progressive weakening over time that I described in the previous section: materials tend to be used up, and memories tend to fade, but no natural fact makes freedom itself become less important over time. However,

64. I consider explanations of statutes of limitations grounded in the loss or increasing irrelevance of benefits over time more plausible than many that are typically offered. For instance, it is often said that criminal statutes of limitations protect defendants who would have difficulty putting forth a case after time has destroyed evidence and clouded minds. See, e.g., Wayne R. LaFave, Jerold H. Israel \& Nancy J. King, Criminal Procedure $\$$ I8.5(a) (2d ed. 1999) (citing Model Penal Code $\$$ I.07 (Proposed Official Draft 1962)). Despite its prevalence, this is an odd claim in view of the burden of persuasion in criminal cases: the fading of evidence should help defendants rather than hurt them, and certainly juries could factor in the reliability of old evidence in deciding whether there was reasonable doubt of defendants' guilt. 
benefits associated with freedom may succumb to a more subtle effect of time-namely, time's ability to change what individuals and society regard as either unfair or, more subtly, important.

To begin to describe the phenomenon I'm introducing, it is important to distinguish it from another kind of argument. Some commentators who discuss statutes of limitations, and others who discuss repentance, argue in terms of the offender's "identity." For example, Rebecca Dresser argues that

a person now might have very weak psychological connections to the person who committed a past crime. This could be due to the passage of several years, or the occurrence of an event that produced sharp psychological discontinuity, such as a religious conversion. [Derek] Parfit proposes that such a person may deserve no punishment, or at least less punishment, than someone very strongly connected to the criminal. ${ }^{\text {.s }}$

As an example from a different line of scholarship, Meir Dan-Cohen explains concisely a view of identity that he rejects as a basis for repentance:

The change wrought by repentance may be so profound as to count as a change of identity. Since the repentant individual is not the same one as the wrongdoer to whom we bore a grudge, the offender's transformation deprives the reactive attitudes of their object. ${ }^{60}$

In place of this view, Dan-Cohen offers an understanding of repentance that allows individuals to redefine the "boundaries of the self" to exclude prior crimes, much as a political state might redefine its spatial boundaries to exclude some territory. ${ }^{67}$

These views, generally, have one thing in common: they emphasize a change that an offender undergoes such that it is no longer appropriate to punish her because, in some sense, the person that remains is not the one who committed the crime. I do not wish to argue this. Instead, I want to make a related but conceprually distinct argument-namely, that the passage of time may, irrespective of what it does to the identity of the offender, cause the benefits the offender received from the crime to matter no

65. Rebecca Dresser, Personal Identiry and Punishment, 70 B.U. L. Rev. 395, 413 (1990).

66. Dan-Cohen, supra note $\mathrm{I}$, at $12 \mathrm{2}-24$.

67. Id. at 9-12. 
longer. Under such a view, we can agree that the offender is still identical with the individual that committed the crime, that the crime is indeed part of the offender's personal history, and so forth, while still deciding that punishment is unjust because there is no longer an unfair advantage to redress (or worth redressing). ${ }^{68}$

To understand how such a decision works, recall the sort of benefit with which we are concerned in this section-what I've called loosely "appropriation of excess freedom." As I have noted, an offender normally retains this freedom even when she has attempted to reverse the effects of her crimes. However, when an offender can no longer think of the crime as having conferred any measure of desirable freedom on her, it is not clear that an unfair advantage remains or needs to be addressed.

Consider first a relared case: one in which the law has decriminalized an offense between the time that it was committed and the time punishment might be imposed for it. In such a case, does any unfair advantage remain for punishment to correct? The offender did once renounce selfrestraint, but the sort of self-restraint she renounced is perhaps of a form that the law no longer considers relevant (by virtue of its having decriminalized the actions associated with such a renunciation). The offender has demonstrated a willingness to break the law, but not necessarily a willingness to break the present law. As a result, punishment under a fair-play account is questionable; the change in law itself may have restored a fair balance between burdens and benefits by indicating retroactively that the benefits offenders received from some actions that are no longer crimes no longer matter. ${ }^{69}$ (It may seem more plausible to suppose that the sort of

68. My argument aims to avoid puzzles that arise from clashes between common conceptions of identity and constructed conceptions that may perform useful analytical work but remain counterintuitive to apply. I do not mean to suggest that I ultimately disagree with Parfit's or Dan-Cohen's views, only that my analysis here does not depend on them.

69. Important distinctions may follow from the different reasons a state may decriminalize activity and my suggestion about what decriminalization indicates (namely, that the benefits offenders once received from actions that are no longer crimes are no longer considered unfair or important) may be correct only for certain kinds of changes in the law. It seems at least possible that a state may mean to say, "We no longer consider this action a crime because circumstances have changed, but we still care very much about prior occurrences." As a result, it is difficult to discuss this case in the abstract. It is sufficient for the analogy I'm drawing that at least sometimes, a state may wish to say, " $X$ is no longer a crime, and no prior commissions of it are relevant to us any longer." 
decriminalization I am discussing indicates that there never was an unfair advantage from certain crimes; we were simply mistaken in thinking so. The problem with that view is that decriminalization is not necessarily an admission that all punishment under the old rule was unjust, or even that the old law was mistaken for its time. Decriminalization may simply imply that certain kinds of "freedom" people once appropriated are not now the sort of things that count as unfair benefits. As a rough analogy, one's wealth may rise suddenly by virtue of society's new emphasis on a formerly worthless good of which one owns a stockpile; the most sensible interpretation isn't that one was always wealthy but that particular states of the world are now interpreted differently.)

Some of the features of a decriminalized offense are also present in the case of an offender who no longer believes that the excess freedom associated with a prior crime is worth having. The advantages of a renunciation of self-restraint are no longer considered relevant in the same way as they once were, although here the subject considering relevance is the offender herself and not (directly) the state. Nonetheless, to the extent that fair-play theory focuses on the offender's benefits, the state may appropriately adopt the offender's point of view in estimating their persistence over time; if fair-play punishment aims to restore a fair balance between benefits and burdens, what is the (fair-play) point of imposing it if we can confidently determine that the offender is no longer the sort of person who considers the excess freedom from her crime a benefit (or, to put this differently, considers it a freedom in the first place) ? ${ }^{70}$

Perhaps this argument will not convince those whose conception of the "freedom" or "renunciation of self-restraint" associated with crime is so abstract that it is divorced altogether from any practical benefits to offenders. Even then, however, cases in which time has passed and an offender no longer sees any value in the freedom she appropriated likely stand as compelling cases for the exercise of mercy-at least for those who

70. Cf. Conklin v. Sloss, 150 Cal. Rptr. 121, 125 (Cal. Cr. App. 1978) (allowing an invasionof-privacy claim to go forward against a defendant who published details about a murder of which the plaintiff had been convicted twenty years earlier; "Plaintiff has alleged facts which, if proven to the trier of fact, would indicate that he has " "reverted to the lawful and unexciting life led by the great bulk of the community,...'" (quoting Restatement of Torts $\$ 867 \mathrm{cmt}$. c (1938)). In Conklin, the plaintiff had already been convicted of a crime; the case nonetheless highlights a situation in which an offender may well derive no "benefic" from a past crime. 
believe mercy can ever be warranted. Or, to gloss this slightly differently, we may simply not feel the need to address all kinds of unfairness equally. For example, just as we may impose lighter punishments for unsuccessful attempts because we may not care as much about cases in which no harm resulted, ${ }^{71}$ we may impose lighter punishments because we may not care that an unfair advantage remains in the abstract when the offender retains no practical benefit from this advantage, sees no value in it, does not identify with it, and may prefer it never existed. In a meaningful sense, the offender did not "get away" with anything. In such cases, does it really matter whether an unfair equilibrium exists ethereally?

Statutes of limitations, accordingly, may in part reflect bright-line rules concerning either (I) our belief that benefits are unlikely to remain from crime after a certain interval has passed, or (2) our belief that benefits are unlikely to be relevant from crime after certain intervals, either because (a) such a lack of relevance to the offender eliminates desert, or (b) such a lack of relevance to the offender translates to a lack of concern by society in redressing an abstract imbalance.

\section{CONCLUSION}

My goal has been to follow the fair-play account of punishment to its logical conclusions in cases where matrers have changed between crime and punishment such that punishment may be unjust. As I suggested at the outset, this sort of application of a theory of punishment by extending it can be applied either as a critique of punishment or as a critique of the theory. On reflection, I find that my intuitions favor the former approach, and thus that my analysis bolsters fair-play theory. That is, my feeling is that punishment does indeed seem unjust in cases where no unfair advantage remains.

In this respect the private-burden cases seem easier to me: duplicating punishment when an offender has already been punished in a private prison replica seems manifestly unfair, even under a transactional view of justice that focuses only on crimes and (some of) their consequences. The

71. Cf. generally Douglas N. Husak, Why Punish the Deserving, 26 Noûs 447,458 (1992) (suggesting that it might be more "important" to restore equilibrium between benefits and burdens in some cases than in others). 
most compelling reason for intentional ignorance of private punishment may be administrative concerns that purportedly necessitate bright-line rules, but merely motioning in that direction does not amount to an argument for such rules. In at least some cases, evidence of suffering will not be hard to find or easy to fake.

The analysis of cases in which benefits have been lost is complicated by confusion over the kinds of benefits fair-play analysis tallies. My goal here has not been to determine a single kind of benefit that matters to the exclusion of all others (although I hope my discussion of benefits and their persistence over time can advance their analysis somewhat). Instead, my goal has been to observe that benefits of any relevance in justifying punishment under a fair-play account seem prone either to being lost over time or to being judged irrelevant over time. This too seems to comport with my sense of justice, of mercy, and of what kinds of unfairness it is important for society to redress. 